\title{
Areas Requiring Restoration Efforts are a Complementary Opportunity to Support the Demand for Pollination Services in Brazil
}

\author{
Pedro J. Bergamo,* Marina Wolowski, Leandro R. Tambosi, Edenise Garcia, Kayna Agostini, \\ Lucas A. Garibaldi, Tiffany M. Knight, Eimear Nic Lughadha, Paulo E. A. M. Oliveira, \\ Marcia C. M. Marques, Pietro K. Maruyama, Márcia M. Maués, Alberto K. Oppata, André R. Rech, \\ Antônio M. Saraiva, Felipe D. S. Silva, Gizele Sousa, Rodrigo Y. Tsukahara, Isabela G. Varassin, \\ Blandina F. Viana, and Leandro Freitas
}

Cite This: https://doi.org/10.1021/acs.est.1c02546

Read Online

\begin{abstract}
ACCESS I
Wlll Metrics \& More

回国 Article Recommendations

Supporting Information

ABSTRACT: Crop pollination is one of Nature's Contributions to People (NCP) that reconciles biodiversity conservation and agricultural production. NCP benefits vary across space, including among distinct political-administrative levels within nations. Moreover, initiatives to restore ecosystems may enhance NCP provision, such as crop pollination delivered by native pollinators. We mapped crop pollination demand (PD), diversity of pollinator-dependent crops, and vegetation deficit (VD) (vis-a-vis Brazilian legal requirements) across all 5570 municipalities in Brazil. Pollinator-dependent crops represented $~ 55 \%$ of the annual monetary value of agricultural production and $\sim 15 \%$ of the annual crop production. Municipalities with greater crop PD (i.e., higher degree of pollinator dependence of crop production) also had greater VD, associated with large properties and monocultures.

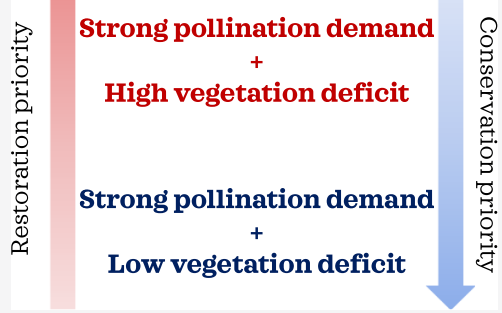

In contrast, municipalities with a greater diversity of pollinator-dependent crops and predominantly small properties presented a smaller VD. Our results support that ecological restoration prompted by legal requirements offers great potential to promote crop productivity in larger properties. Moreover, conservation of vegetation remnants could support food security in small properties. We provided the first steps to identify spatial patterns linking biodiversity conservation and pollination service. Using Brazilian legal requirements as an example, we show that land-use management policies may be successfully used to ensure agricultural sustainability and crop production.
\end{abstract}

KEYWORDS: agriculture, biodiversity conservation, crop pollination, ecological intensification, ecological restoration, ecosystem services, landscape planning, sustainability

\section{INTRODUCTION}

Reconciling biodiversity conservation and crop production is critical to secure human wellbeing. In this context, the concept of Nature's Contributions to People (NCP) postulates that nature provides goods and services that support human landscapes functioning. ${ }^{1}$ To integrate ecosystem services and NCP concepts in agriculture, landscapes must be designed to be productive while maintaining ecosystems and their services. ${ }^{2}$ We can envision such landscapes because biodiversity provides services that enhance crop productivity., However, extensive agriculture is still the major cause of land use change and habitat loss globally. ${ }^{5}$ Given projections of increased global demand for food, ${ }^{6}$ there is an urgent need to reverse the current trend of agricultural expansion by promoting sustainable agricultural practices. Ecological restoration is one potential solution to recover natural areas and sustain NCP. ${ }^{7,8}$ Globally, there is potential for ecological restoration of almost $1 \mathrm{bi}$ ha, even without considering agricultural land. ${ }^{9}$ Thus, we now have the opportunity to plan ecological restoration initiatives in conjunction with other human activities such as agriculture. ${ }^{10}$

One critical NCP with potential to reconcile biodiversity conservation and sustainable agriculture is pollination. Several important crops depend on biotic pollination provided by wild animals such as bees, flies, butterflies, beetles, and vertebrates, ${ }^{11-13}$ which may be equally or more effective than managed pollinators. ${ }^{14,15}$ An increased demand for pollinator-dependent crops $^{13,16}$ represents an opportunity to plan integrated biodiversity conservation and agricultural practices via provision of crop pollination services. Native

Received: April 19, 2021

Revised: July 26, 2021

Accepted: July 27, 2021 
vegetation near to farmed areas maximizes pollination services, thereby enhancing crop productivity ${ }^{3,4,17}$ and stability. ${ }^{18}$ Thus, managed landscapes may contribute to ecosystem functioning and agricultural production. ${ }^{19-21}$ In this context, it is important to design environmental policies that integrate biodiversity conservation and crop pollination.

To plan effective landscapes, it is necessary to understand the demand for NCP in each locality. The demand for crop pollination services at global and national scales has most frequently been assessed through the dependence ratio method. ${ }^{11,12}$ In this method, pollinator contribution for each crop is valued based on the crop's dependence on biotic pollination and monetary value. ${ }^{11,12}$ Estimates of the total economic demand for crop pollination services are now available at global, ${ }^{22-25}$ national, $^{26}$ and local scales. ${ }^{27-30}$ However, national estimates mask the spatial variability of the agricultural landscape and of levels of pollinator dependence across a country. A broad-scale assessment considering smaller units is important because decision making and conservation actions are often undertaken for smaller administrative units, and thus, there is a need for precise estimates at such a scale. One way to account for small-scale variation is to estimate crop pollination demand (PD) within smaller administrative units such as counties or municipalities. ${ }^{29,30}$ However, this is rarely undertaken for all municipalities across broader scales such as countries or continents. ${ }^{31}$ Moreover, metrics other than dependence ratios based on the monetary value may be important to understand the relationship between land use patterns and crop pollination. For instance, dependence ratios based on crop production or occupied area can be particularly informative due to their more direct relationship with the extent of the agricultural area. Furthermore, the type of agriculture can vary widely across regions in a country, from large properties with extensive or intensive monocultures to small properties with high diversity of cultivated crops. ${ }^{32}$ Therefore, metrics that describe crop diversity may reveal distinct scenarios of demand for crop pollination $^{33}$ (e.g., monocultures of crops such as soybean that show a relatively modest increase in production due to pollinators vs diverse planting of medium to highly pollinatordependent crops).

In addition to demand for crop pollination, for effective planning of managed landscapes it is necessary to consider land use patterns. ${ }^{2}$ Although studies often focus on landscape metrics known to influence crop pollination, , $^{3,4,17,34}$ they do not use metrics that take into account any relevant legal environmental requirement when proposing pollinationtargeted restoration policies and practices. Thus, an approach that integrates demand for NCP and legal restoration requirements can provide an assessment of areas with potential for immediate restoration efforts in concert with economic and human wellbeing benefits. In this context, Brazil stands out as one of the world's leading producers of food and agricultural commodities $^{6}$ while also being home to one of the largest portions of the world's biodiversity. ${ }^{35}$ Moreover, Brazil's variety of ecosystems, land management systems, and practices $^{32,35,36}$ offers a wide range of scenarios to understand where biodiversity-driven NCP is needed the most. The continental scale of Brazil also provides a unique opportunity to assess demand for NCP and restoration requirements due to the availability of standardized information about agricultural production and land use patterns across a large area. ${ }^{36}$ Environmental legislation regulates the amount of natural vegetation required to be conserved in each property (Brazilian Native Vegetation Protection Law ${ }^{37}$ ). Vegetation deficit (VD) (i.e., the shortfall in native vegetation within properties to comply with minimum legal requirements) is estimated at 19 million ha in Brazil. ${ }^{38}$ Thus, the current legal requirement to restore natural vegetation represents a unique opportunity, with significant gains for biodiversity conservation and agriculture. $^{39,40}$ Nevertheless, demand for crop pollination has been assessed only for Brazil as a whole, ${ }^{41,42}$ as in other countries. $^{26}$ In this context, mapping the demand of crop pollination in relation to VD across municipalities can be the first step to identify scenarios in which implementation of restoration efforts can present a win-win outcome with direct benefits for both biodiversity recovery and crop production.

Here, we explore how crop PD is associated with VD by using information at the Brazilian municipality level. We estimated the total crop PD (based on the crop monetary value, production, and area) in Brazil. Then, we mapped scenarios in which restoration efforts would meet demand for crop pollination and others in which conservation of natural areas would be particularly important to maintain pollination services. The information provided here is the first step toward effective planning of managed agricultural landscapes at a country-wide scale that incorporates the benefits arising from pollination services which accrue to biodiversity conservation and agricultural production.

\section{MATERIALS AND METHODS}

2.1. Crop Production Data. We used data of crop market value, production (ton), and cropland area (ha) of all 184 crops per municipality available from the Brazilian Institute of Geography and Statistics (IBGE) database for the year 2017 (https://sidra.ibge.gov.br/pesquisa/pam), the latest with available information on VD at the municipality level. ${ }^{38}$ These data result from a large agricultural census conducted in 2017 by IBGE and accounting for all production value across Brazil, following the FAO World Programme for the Census of Agriculture 2020 guidelines. Here, we present crop value data in US\$, using the mean conversion value of 2017 (1US\$3.20R\$, available at the Central Bank of Brazil-https://bcb. gov.br/estabilidadefinanceira/historicocotacoes). Of Brazil's 5570 municipalities, we excluded those which lacked the required information (monetary value, production, and area), then compiled information on the crop monetary value for 184 crops in 5524 municipalities, on crop production for 184 crops in 5064 municipalities, and on crop area for 94 crops in 5149 municipalities.

2.2. Crop Dependence on Pollinators' Data. We obtained the pollinator dependence ratio (PDR) for 128 cultivated crops in Brazil from national databases. ${ }^{41,42}$ Updated information for a further 17 crops was gathered from previous studies conducted in Brazil that evaluated crop yields in the presence and absence of animal pollinators, that were found on Web of Science, Scopus, Scielo, and Google Scholar platforms using the following search strings: crop name (in English) AND pollinat*; crop name (in Portuguese) AND poliniz*. Values for PDR were then estimated following a standard methodology. ${ }^{11}$ In addition, for 30 crops with no information on pollination studies in Brazil, we used PDR values from international databases. ${ }^{11}$ Finally, for three crops, we estimated PDR using studies conducted in other countries. In total, we compiled information for 178 of 184 crops (96.7\%). All crops, 
data sources, and methodological details are presented in Table S1.

Approximately half of the recorded crops in our database (90 of 184, 48.9\%) showed some degree of pollinator dependence. The latest assessment of pollination services reported $69(76 \%)$ pollinator-dependent plants among 91 cultivated and wild plants used for food production in Brazil. ${ }^{42}$ Here, we also included crops not used for food production, in order to have estimates of the contribution of pollinators in relation to all agricultural production in Brazil. Moreover, we only considered pollinator-dependent crops for which pollinators increase yields of the commodity of the crop (i.e., fruits and/or seeds in trade). Importantly, 94 of 184 crops $(51.1 \%)$ in our database have no direct relationship with animal pollinators (being wind-pollinated, e.g., sugar cane, or completely selfing, e.g., pineapple) or have an indirect benefit of pollinators (whereby pollinators increase seed production but not the commodity of the crop, e.g., onion). Crops with an indirect benefit from pollination represented less than $0.004 \%$ of total crop production, and their inclusion would likely not substantially change the results. Thus, our estimates consider only the "direct contribution of pollinators" 31 and can be considered realistic in relation to the agricultural activity of each municipality.

2.3. Estimating Demand for Crop Pollination. We used crop data (monetary value, production, and cropland area) to estimate three metrics describing crop PD in each municipality. Crop monetary value demand (i.e., potential contribution of pollinators to the crop monetary value in a municipality) was estimated by multiplying the market value of each crop in each municipality by its $\mathrm{PDR}^{23}$ We adopted the following classification of PDR classes: essential-PDR $=0.95$ (i.e., 90$100 \%$ of crop yield dependent on animal pollinators); great$\mathrm{PDR}=0.65$ (40-90\% dependence); modest $-\mathrm{PDR}=0.25$ (10-40\% dependence), little-PDR $=0.05 \quad(0.1-10 \%$ dependence), and no dependence-PDR $=0 .{ }^{11}$ To obtain the crop PD per municipality, we summed crop monetary value demand for all crops in a given municipality and divided it by the total crop market value for each municipality. ${ }^{23} \mathrm{We}$ repeated the same procedures using the crop production and crop area data to estimate crop production demand (potential contribution of pollinators to crop production in a municipality) and crop area demand (potential contribution of pollinators in relation to total cropland area in a municipality). Taking into account that PDRs are based on the variability of pollination contribution for crop production, ${ }^{11}$ we also calculated all demand metrics using the lower and upper ranges of each PDR class as a measure of uncertainty. ${ }^{31}$

We classified the level of demand of each municipality based on the distribution of values of each metric separately (crop monetary value demand; crop production demand; and crop area demand). The highest quartile indicates "strong demand," the second highest quartile indicates "great demand," the third quartile indicates "intermediate demand," and the fourth quartile indicates "weak demand."

In addition, we identified which pollinator-dependent crops were the most important in each municipality. For this, we assessed which pollinator-dependent crop exhibited the highest demand (i.e., accounted for the highest production dependent on animal pollinators measured as the crop production multiplied by the dependence ratio) in each municipality.

2.4. Estimating Diversity of Pollinator-Dependent Crops. We used the crop production data to estimate the diversity of pollinator-dependent crops. For this, we used an index of species diversity widely used in ecological studies, the Shannon index. ${ }^{43}$ We included the crop diversity metric in order to capture agricultural diversity ${ }^{32}$ (e.g., large monocultures of soybean in Central Brazil ${ }^{44}$ vs agroforestry systems in the Amazon ${ }^{45}$ ). To this end, instead of using the proportion of species $i$ relative to the total number of species (pi) for each community, we calculated the proportion of each pollinatordependent crop production relative to the total production of all pollinator-dependent crops in a given municipality. Low values of the diversity of the pollinator-dependent crop index represent production dominated by a few pollinator-dependent crops in a municipality (characterizing extensive or intensive monocultures typical of large properties). On the other hand, high values represent a high number of pollinator-dependent crops produced in relatively even proportions in a municipality (characterizing diversified systems typical of small properties).

To confirm that diversity of the pollinator-dependent crop index can be used as a surrogate of agricultural diversity, we used the information on the most produced (in tonnage) pollinator-dependent crop in each municipality. To do this, we evaluated whether diversity of pollinator-dependent crops differed between municipalities in which soybean was the most produced crop versus other municipalities, using linear models. We chose soybean because it is a crop characterized by largescale monocultures in Brazil. ${ }^{44,46} \mathrm{We}$ acknowledge that pollinator dependence of soybean is still controversial because the degree of dependence may vary between distinct varieties. $^{41}$ Thus, we followed previous classifications of the modest pollinator dependence for soybean, even though some empirical studies have reported higher dependence. ${ }^{41,42}$ Indeed, "soybean municipalities" showed lower values of diversity of pollinator-dependent crops in comparison with other municipalities (Shannon index: $0.29 \pm 0.35$ vs $0.95 \pm$ $0.59, \beta$ estimate $=-1.20 \pm 0.05, t=-25.24, p<0.001)$. Therefore, this metric is useful to identify municipalities with a high production of soybean and thus large-scale monocultures. $^{44}$

We classified the pollinator-dependent crop diversity of each municipality based on the distribution of the diversity metric. The highest quartile indicates "highest diversity," the second highest quartile indicates "great diversity," the third quartile indicates "intermediate diversity" and the fourth quartile indicates "low diversity." Although representing distinct aspects of crop importance, our three crop PD metrics (based on the monetary value, production, and area) were highly correlated (see the results and discussion section) and, thus, would produce similar estimates of diversity of pollinatordependent crop values.

2.5. Vegetation Deficit. We used data on legal VD of Brazilian municipalities in 2017 (the most recent complete data set per municipality available). ${ }^{38}$ Legal VD is the difference between the amount of native vegetation within each property and the minimum required by the national environmental legislation, specifically the Native Vegetation Protection Law. ${ }^{37}$ VDs were estimated with land tenure maps. ${ }^{36}$ In brief, farmers must conserve two target areas in their farmland: permanent preservation area-PPA and legal reserve-LR. PPA encompasses native vegetation required in buffer zones close to areas of special conservation interest (e.g., water bodies and mountain tops). ${ }^{37}$ LR refers to the total area of the property that should be kept as native vegetation, which varies from 20 to $80 \%$, depending on the biome. ${ }^{37}$ To achieve 
a single and comparable number per municipality, the total area that should be allocated to native vegetation in order to fulfill the minimum requirements of PPA and LR was divided by the total area occupied by private properties. Using the distribution of VD data, each municipality was classified as "high VD" (above the median) or "low VD" (equal or less than the median) (Figure S1). Additionally, we also mapped the absolute area of deficit per municipality (Figure S1). This was done because some municipalities in Brazil have extremely large areas, which may result in a low relative VD but would still mean a large absolute area of legal deficit.

2.6. Crop Pollination in Relation to Vegetation Deficit. To verify whether crop PD and crop diversity are associated with VD, we tested the correlation between each crop pollination metric and VD with Spearman's rho. Then, we mapped scenarios in which restoration has potential to enhance pollination services. For this, we combined the classifications of crop PD and diversity of pollinator-dependent crops with categories of VD. Here, we treated the third and fourth quartiles of demand as the "weak demand" category. Similarly the third and fourth quartiles of the diversity of pollinator-dependent crops were treated as the "low diversity" category. We did this to achieve a simpler classification based on fewer categories. Consequently, our classification can be considered conservative since half of the municipalities will fall in the "weak demand" (or low diversity) category.

The combination of crop PD metrics (monetary value, production, and area) and VD was used to rank restoration and conservation priorities aimed at providing crop pollination services (Figure 1). Municipalities with high VDs are

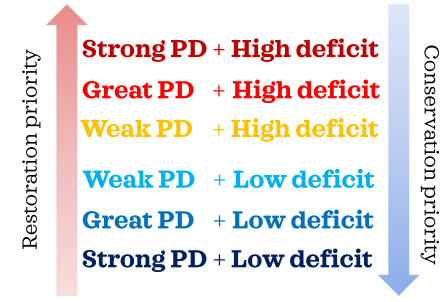

Figure 1. Illustrative scheme showing how crop PD and VD were used to rank restoration and conservation priorities. Municipalities with high VD are restoration priorities, as required by the environmental law. Among these, we scored priorities for restoration aimed at providing crop pollination services: highest priority (strong/ great $\mathrm{PD}$-red) and lowest priority (weak demand-yellow). Municipalities with low VD are priorities for conservation of natural areas and maintenance of restoration efforts. Among these, we provided priority scores for conservation efforts aimed at providing crop pollination services: highest priority (strong/great PD-dark blue) and lowest priority (weak PD-light blue).

restoration priorities, as required by the Native Vegetation Protection Law. ${ }^{37}$ Among these, we scored priorities for restoration aimed at providing crop pollination services: highest priority (strong/great PD + high deficit) and lowest priority (weak PD + high deficit). Municipalities with low VD are priorities for conservation of natural areas and maintenance of restoration efforts. Among these, we provided priority scores for conservation efforts aimed at providing crop pollination services: highest priority (strong/great PD + low deficit) and lowest priority (weak PD + low deficit). Moreover, the combination of diversity of pollinator-dependent crops and VD was used to identify regions in which restoration priorities could be related to the agricultural diversity (e.g., extensive or intensive monocultures typical of large properties vs diversified systems typical of small properties).

All maps were produced with QGIS using the Brazilian municipalities boundaries. ${ }^{47}$ To facilitate interpretation of spatial patterns, we used the Brazilian administrative regions (Northern, Northeastern, Central-Western, Southeastern, Southern, see Figure 2A), biome classification according to international ecoregions ${ }^{48}$ (Tropical forests-known as "Amazon" and "Atlantic Forest"; dry forest-known as "Caatinga," Savanna-known as "Cerrado," Wetland-known as "Pantanal," and Grassland-known as "Pampa," see Figure 2B), and highlighted the "Brazilian deforestation arc" in the Amazon $^{49}$ (Figure 2C). Administrative regions and biome boundaries followed IBGE.

\section{RESULTS AND DISCUSSION}

Using a data set comprising more than 5000 municipalities, we showed that higher demand for crop pollination (PD - i.e., stronger pollinator dependence of crop production) coincided with higher vegetation deficit (VD) in Brazil. Nevertheless, there was a wide spatial variation in the association between crop PD and VD that reflects distinct economic and land use scenarios. Thus, a key implication of our results is the importance of local scale information as a basis for decisionmaking and conservation policies. Importantly, we compiled available information from public governmental institutions, NGOs, and universities to generate an integrated assessment across a large country. Our results can help develop sustainable solutions for agriculture, including identifying target areas for conservation and restoration to enhance productivity of economically important crops.

\subsection{CROP POLLINATOR DEPENDENCE}

Among the 90 pollinator-dependent crops, the contribution of pollinators is essential for 34 crops $(37.8 \%$, dependence ratio between 90 and 100\%), great for 27 (30\%, dependence ratio between 40 and $90 \%)$, modest for 20 (22.2\%, dependence ratio between 10 and $40 \%$ ), and little for 10 (9\%, dependence ratio between 0.1 and 10\%) (Table S1).

Overall, the 184 crops in our data set comprised an agricultural production of US\$ 84 billion, resulting from 866 billion tons in 2017. The 90 pollinator-dependent crops represented an agricultural value of US\$47 billion and a production of 137 billion tons in 2017 (without weighting by pollinator-dependence levels). Thus, pollinator-dependent crops comprised $55.3 \%$ of the total monetary value of agricultural production and $15.2 \%$ of the total production. The absolute value of animal crop pollination (absolute value of crop production weighted by pollinator-dependence levels) was approximately US\$ 13 billion, comprising a production of 42 billion tons. In other words, animal crop pollination represented $15.6 \%$ of the total monetary value of agricultural production and $4.8 \%$ of the total production (tonnage).

We found high variation in the absolute value of animal crop pollination (absolute monetary value weighted by pollinatordependence levels) within Brazilian administrative regions, even between municipalities close to each other (Figure 3A). Overall, animal crop pollination was most important in municipalities located in the Southern, Southeastern, and Central-Western regions and in some municipalities in the Amazon near the "Brazilian deforestation arc" (Figure 3A). In 
$\mathbf{A}$

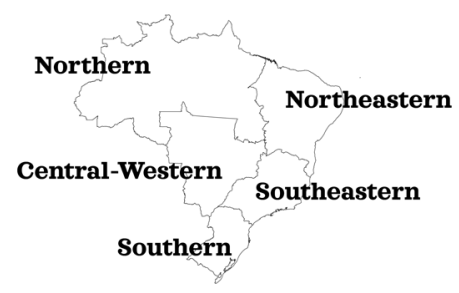

B

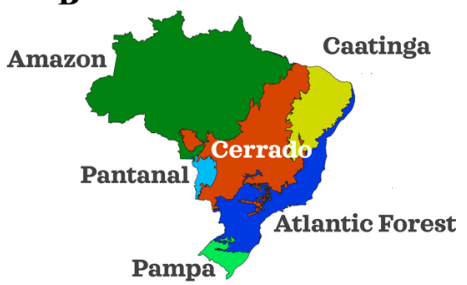

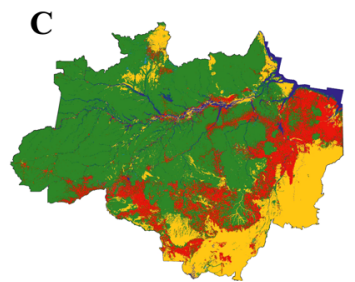

Figure 2. Maps illustrating the study area. (A) Map of Brazilian regions. (B) Map of Brazilian biomes. The biome names correspond to tropical rainforests (Amazon and Atlantic Forest), dry forest (Caatinga), savanna (Cerrado), wetlands (Pantanal), and grasslands (Pampa). (C) Map of change in land use cover in the Legal Amazon for the period of 1988-2017 (data from PRODES, http://terrabrasilis.dpi.inpe.br/app/map/ deforestation). Green indicates native Amazon forest, blue indicates water bodies, and orange indicates native non-forest area (Savannah biome and savannah-like vegetation within the Amazon biome). Red indicates areas in which native vegetation was converted to agricultural (including pasture) activities, accumulated for the period of 1988-2017. This area is known as the Amazonian deforestation arc. ${ }^{49}$

A

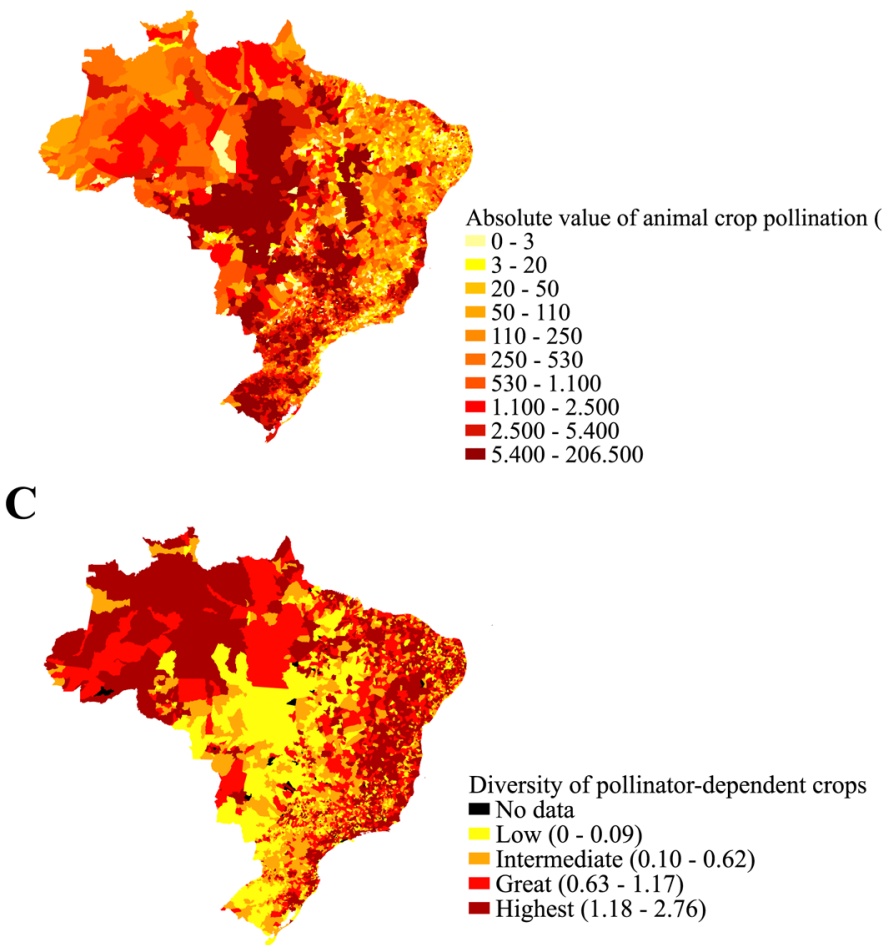

B

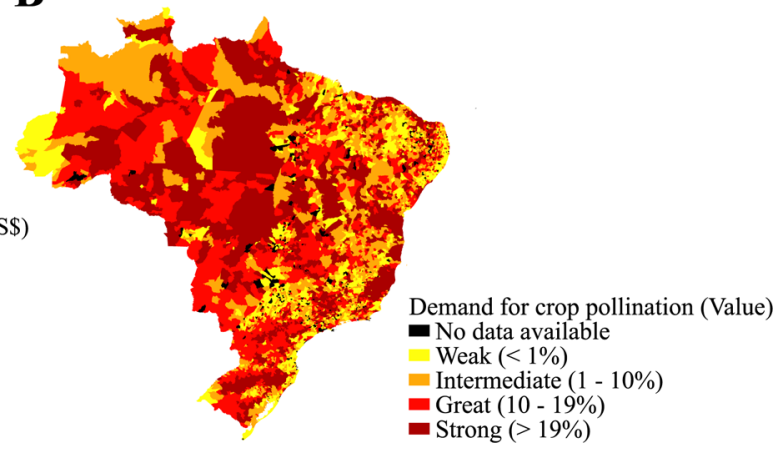

D

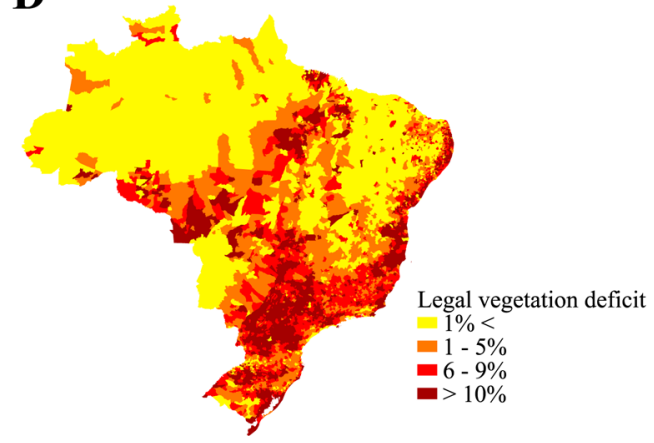

Figure 3. Crop pollination metrics across the Brazilian municipalities. (A) Absolute values of animal crop pollination (absolute monetary value in US\$ weighted by pollinator-dependence values, evaluated using the dependence ratio method ${ }^{11,12}$ ). (B) Demand for crop pollination (monetary value of crop pollination relative to the total monetary value of agricultural production). (C) Diversity of pollinator-dependent crops. For all metrics, we created categories based on the quartiles. The first quartile indicates weak demand (or low diversity), the second quartile indicates intermediate demand (or diversity), the third quartile indicates great demand (or diversity), and the fourth quartile indicates strong demand (or high diversity). (D) Legal vegetation deficit (percentage of area in legal deficit in relation to the total municipality area).

contrast, animal crop pollination was least important in municipalities concentrated in the Northeastern region (Figure 3A).

The absolute value of animal crop pollination estimated for 2017 ( US\$13 bi) was similar to that estimated for 2018 in Brazil ( US\$13.4 bi). ${ }^{42}$ This economic contribution is in large part due to soybean, highlighted here by the high number of municipalities in which soybean showed the strongest demand for pollination. Moreover, soybean alone accounted for $60.6 \%$ ( US\$ 7.8bi) of the absolute monetary value of animal pollination. Previous studies have shown that a shortage of pollinators decreases soybean production by $20-30 \% .{ }^{50-52}$ In 
this context, the projected increase in soybean production in Brazil $^{46}$ will increase demand for pollination services. However, soybean production expansion has been associated with conversion of native areas to cropland causing massive deforestation in the Cerrado and Amazon forest. ${ }^{53-55}$ Such land conversion might increase VDs and reduce the provision of pollination services, leading to decreased crop productivity. For instance, there is evidence that soybean plantations located up to $100 \mathrm{~m}$ from large forest patches of $>110$ ha had higher pollinator visitation rates and crop yields (seeds per plant) than plantations far from natural areas. ${ }^{52}$ Large forest patches also guarantee long-distance pollination in soybean plantations, ${ }^{52}$ which indicates that even in landscapes dominated by monocultures, restoration may still benefit crop productivity. Thus, landscape planning is needed to maximize crop pollination benefit in important crops, even those with modest pollinator dependence such as soybean. ${ }^{42}$ Such potential tradeoffs between increased crop PD and decline of service provision in Brazil are part of a global trend. ${ }^{13}$ Therefore, if we are to meet the increasing demand, it is necessary to protect and increase the supply of pollination services by restoring natural vegetation, including areas of extreme deforestation.

\subsection{CROP POLLINATION DEMAND AND DIVERSITY OF POLLINATOR-DEPENDENT CROPS}

There was a wide variation in crop PD across Brazilian municipalities: demand in the monetary value varied from 0 (no demand) to 0.93 (where 93\% of the crop monetary value is reliant on animal pollination), demand in crop production also varied from 0 to 0.93 , and demand in occupied area varied from 0 to 0.95 . There was a high correlation between demand metrics (monetary value, production, and area; Spearman's rho $=0.76-0.87$, all $p<0.001$, Table S2). The level of demand for crop pollination (in monetary value) varied considerably across Brazilian municipalities (Figure 3B). Municipalities with a strong demand ( $>19 \%$ of the crop value dependent on animal pollination) were concentrated in Southern and CentralWestern regions and also some municipalities in the Amazon close to the deforestation arc and along the Atlantic coast (Figure 3B). Municipalities with a great demand (10-19\%) were distributed across Central-Western and Southern regions, as well as in the Northern region (mainly Western Amazonia) (Figure 3B). Municipalities with intermediate and weak demands $(0-10 \%)$ were concentrated in the Northeastern region, as well as in some portions of the Northern and Southeastern regions (Figure 3B). Patterns across the Brazilian territory were similar when using demand based on crop production and area, reflecting their high correlation with crop monetary value demand (Figures S2 and S3). Uncertainty in $\mathrm{PD}$ was most pronounced in the Central-Western region, coinciding with areas of large soybean monocultures (Figure S4). This is due to the importance of soybean to the PD metrics, which highlights the concerns regarding the accuracy of estimation of pollinator dependence of soybean.

The pollinator-dependent crops that generated most demand for pollination (i.e., contributed most to the estimate of $\mathrm{PD}$ in a given municipality) were soybean (in 1574 municipalities - $25 \mathrm{mi}$ tons dependent on pollinators), watermelon (630-785 ktons), pumpkin (582-396 ktons), coffee (366-779 ktons), and orange (325-3 mi tons) (Figure S4). These were followed by beans (mainlyPhaseolus vulgaris, 265421 ktons), passion fruit (149-248 ktons), coconut (133-230 ktons), tomato (133-285 ktons), and zucchini (88-150 ktons) (Figure S5).

The diversity of pollinator-dependent crops also presented large variation, from 0 (no production of pollinator-dependent crops in a given municipality) to 2.76 (several pollinatordependent crops produced in similar proportions in a given municipality). Diversity of pollinator-dependent crops was weakly and negatively correlated with demand metrics (Spearman's rho $=-0.15--0.06$, all $p<0.001$, Table S2). Diversity of pollinator-dependent crops showed some distinct patterns across the Brazilian territory in comparison with crop PD metrics (Figure 3C). Municipalities with highest diversity of pollinator-dependent crops $(1.18-2.76)$ were concentrated in the Northern and Northeastern regions and along the Atlantic coast (Figure 3C). Similarly, municipalities within the second diversity quartile $(0.63-1.17)$ were also located in the Northern and Northeastern regions and along the coast (Figure 3C). In contrast, municipalities in the third and fourth quartiles $(0-0.62$, i.e., low number of pollinator-dependent crops with some crops dominating overall production) were mostly concentrated in Central-Western, Southeastern, and Southern regions (Figure $3 \mathrm{C}$ ).

Here, we showed a wide variation in the demand for pollination services across Brazil, which supports the urgent need to understand where the provision of each NCP is critically required. ${ }^{56}$ Our results also indicated that such variation is associated with different types of rural properties: from large properties dedicated to commercial monocultures to small properties with a great variety of crops for subsistence. $^{44,57}$ Nevertheless, other factors not considered here such as climate, principal economic activities, and historical changes in land use, may also modulate the association between demand for pollination services and type of property. ${ }^{13}$ Moreover, the demand for crop pollination overlapped with requirements for recovering natural areas to comply with the environmental law, in several areas of the country.

The demand for crop pollination coincided in part with areas in which pollinators had a high absolute economic contribution, that is, large properties associated with highprofit monocultures in Central-Western, Southern, and Southeastern regions. ${ }^{44}$ Additionally, there was a strong demand and crop diversity in the Amazon, in coastal areas, and in the Northeastern region. This strong demand and crop diversity primarily reflect traditional pollinator-dependent monocultures other than soybean in Brazil (e.g., coffee, orange, and cocoa) but also more diverse systems based on fruit and vegetable crops (e.g., watermelon, pumpkin, and tomato) cultivated in intermediate and small properties. ${ }^{57}$ Strong crop PD and crop diversity are also associated with native crops (passion fruit and cashew nut) and Amazonian products (açai palm and babassu oil), strongly dependent on native forested areas. ${ }^{45,58-60}$ Thus, there is wide potential for greater integration of natural and agricultural landscapes, reflecting specific crop PDs. ${ }^{2}$ While some areas will require intensive restoration of native vegetation (i.e., strong demand in areas of high VD), other areas offer the opportunity for integrated management practices focused on both biodiversity and crop productivity (i.e., strong demand in areas of low VD). 
A

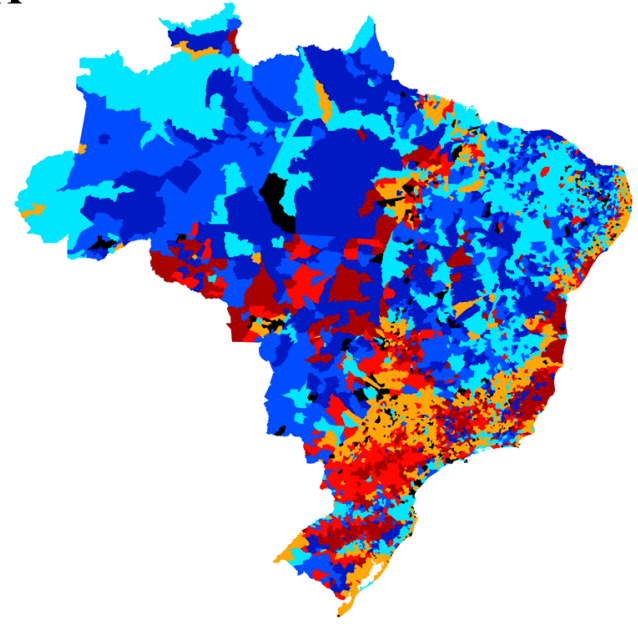

Priority score (value demand + vegetation deficit) - High (strong demand + high deficit) - High (great demand + high deficit) Low (intermediate/weak demand + high deficit) Low (intermediate/weak demand + low deficit) - High (great demand + low deficit) - High (strong demand + low deficit) - No data available
B

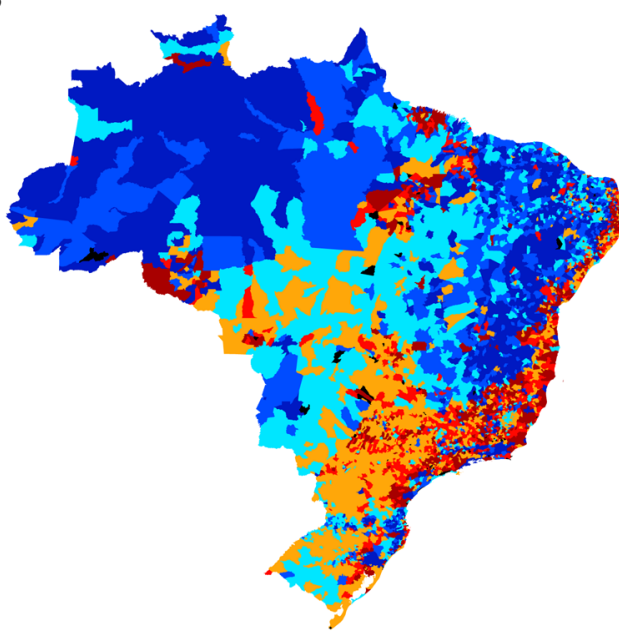

Pollinator-dependent crop diversity + Vegetation deficit - Highest diversity + High deficit - Great diversity + High deficit - Intermediate/low diversity + High defici Intermediate/low diversity + Low deficit - Great diversity + Low deficit - Highest diversity + Low deficit - No data available

Figure 4. Combination of crop pollination metrics and VD in Brazilian municipalities. (A) Combination of demand for crop pollination (based on the crop monetary value) and VD was used to score restoration and conservation priorities aimed at providing crop pollination services. Municipalities with high VD are restoration priorities, as required by the environmental law. Among these, municipalities were classified in highest (strong/great crop PD) to lowest restoration priority (weak demand). Municipalities with low VD are priorities for conservation of natural areas and maintenance of restoration efforts. Among these, municipalities were classified in highest (strong/great demand + low deficit) to lowest conservation priority (weak demand). (B) Combination of diversity of pollinator-dependent crops and VD was used to identify regions in which restoration priorities could be related to the agricultural diversity. High crop diversity is associated with a variety of crops produced in similar amounts in a municipality, while low crop diversity is associated with dominance of a single crop (monoculture).

\subsection{ASSOCIATION BETWEEN CROP POLLINATION VARIABLES AND VEGETATION DEFICIT}

Overall, we found negative correlations between the four crop pollination metrics and VDs (Figure S6). The exception was crop area demand, which was not correlated with VD (rho = $0.02, p=0.270$ ). Crop monetary value demand was weakly correlated with VD (rho $=-0.05, p<0.001$ ), while crop production demand showed a stronger negative correlation with VD (rho $=-0.15, p<0.001$ ). Among crop pollination metrics, diversity of pollinator-dependent crops showed the highest negative correlation with VD ( rho $=-0.19, p<0.001)$. In other words, municipalities with low diversity of pollinatordependent crops tend to exhibit high VD (Figure S6). The relatively low correlation values may be related to the nature of legal VDs which differ from biome to biome. Areas with a high deficit in biomes with stricter legal requirements (e.g., up to $80 \%$ of native vegetation cover in properties in the Amazon) may retain higher native vegetation cover than properties in areas with less stringent requirements.

Priorities for restoration and conservation of natural areas aimed at providing pollination services varied widely across Brazil (Figure 4). We identified municipalities where high VD (in which restoration is critically needed) coincides with high demand for crop pollination based on the crop value (Figure $4 \mathrm{~A})$. These were located mainly close to the Amazon deforestation arc, in some municipalities of Central-Western, Southeastern, and Southern regions and along the coast (Figure 4A). Importantly, several of these municipalities also showed a large absolute area with VD (Figure S3). Nevertheless, a few municipalities in the Northern region showed a low relative deficit but a large absolute deficit ( $>42 \mathrm{mi} \mathrm{ha}$ ), and thus, restoration is critically needed: São Félix do Xingu, Cumaru do Norte, Juara, Marabá, and Três Lagoas. We also identified municipalities where low VD coincides with high demand for crop pollination (Figure 4A), in which conservation of native vegetation and maintenance of any existing restoration efforts are strategic to provide crop pollination services. These were mostly concentrated in the Northern region, in some parts of the Central-Western region (especially at the Pantanal biome) and in the Northeastern region (Figure 4A). Maps produced with the metric of demand based on crop production and area showed similar patterns (Figures S7 and S8).

We showed that areas of massive deforestation (e.g., Amazon deforestation $\operatorname{arc}^{49}$ and the Atlantic forest in the Brazilian coast ${ }^{61}$ ) coincided with strong demand for crop pollination. In this context, it is important to reverse the current practice of agricultural expansion in which large areas are converted for extensive stockbreeding and/or monocultures, causing pollinator declines. ${ }^{13}$ Instead, ecological intensification via biodiversity-driven provision of services can be used as means to increase crop productivity. ${ }^{62,63}$ Here, we highlight the opportunity for immediate action through restoration efforts, as already imposed by Brazilian legal requirements of vegetation protection in private properties. Spatial planning of restoration has started to incorporate other NCP such as carbon stocks. ${ }^{64}$ In addition, incorporating crop $\mathrm{PD}$ can produce reliable restoration targets with direct benefits to landowners in Brazil. Landscapes favorable to pollinators are also important to landowners that may not benefit directly from crop pollination services (e.g., owners of properties with large-scale areas for cattle) because pollinators may facilitate 
natural regeneration ${ }^{65}$ and thus promote restoration efforts in order to comply with the environmental law. Importantly, restoration is one of the available practices to reconcile biodiversity conservation and agriculture, but it may be difficult to conduct in extensive monoculture matrices. Thus, other practices (e.g., flower strips) may be equally or more adequate to ensure resources for native pollinators and crop productivity.

We identified restoration priorities according to the agricultural diversity of each municipality (Figure 4B). Municipalities with a high VD and characterized by low diversity of pollinator-dependent crops (i.e., likely to have intensive monocultures) were concentrated in Central-Western, Southeastern, and Southern regions and close to the Amazon deforestation arc (Figure 4B). In contrast, municipalities with high VD and characterized by high diversity of pollinator-dependent crops were distributed along the Atlantic coast (Figure 4B). We also highlight regions in which most municipalities showed a low VD in association with high diversity of pollinator-dependent crops: across the Northern and Northeastern regions, especially in the Caatinga Dry forest (Figure 4B).

Municipalities characterized by a high diversity of pollinatordependent crops coincided with low VDs. This may indicate current agricultural practices favorable for biodiversity conservation in Brazil, in contrast to large monocultures. For instance, small properties often employ sustainable practices such as agroforestry or intercropping, ${ }^{66}$ and our results indicate that conserving native vegetation has a potential to increase economic benefits to these landowners. Therefore, it is important to keep diversified cropping systems and incentivize the protection of native vegetation in order to maintain the supply of crop pollination services in these areas. Most of these high diversity and low deficit municipalities are concentrated in the Amazon and Northeastern region. In the Northeastern region, especially in the Caatinga, small subsistence properties cultivate diversified cropping systems that enhance local production and food security. ${ }^{67}$ In this context, conservation of native vegetation aimed at providing crop pollination may also be used to promote other essential NCP related to food security and rural development. ${ }^{68}$

This assessment of crop PD across a whole country is the first step for biodiversity conservation planning associated with the concept of NCP and crop production. A further step is mapping the potential supply of such services. ${ }^{69}$ The supply of pollination services depends on the quality of native vegetation adjacent to areas of high $\mathrm{PD},{ }^{70}$ a variable not considered here. Moreover, crop pollination can also be viewed as a service linked to several other natural, social, and economic aspects (e.g., cultural practices linked to agriculture, employment, and rural development), making it important to consider multidimensional facets of NCPs. ${ }^{17,28}$ Mapping the diversity of pollinator-dependent crops also indicated the need to consider several crop pollinators because many crops require distinct species of pollinators to maximize the yield. ${ }^{14,15}$ In consequence, restoration practices also need to consider requirements of native pollinators in each area. Future studies should also consider refining the assessment of crop PD by crop class (e.g., fruits and oilseed) given their differing pollinator-dependence levels. ${ }^{11}$

We mapped demand for crop pollination and the diversity of pollinator-dependent crops across VDs in Brazil. Therefore, we could identify municipalities where there is a need to restore and conserve natural areas that directly benefit landowners through provision of crop pollination services. Importantly, regions characterized by extensive monoculture or by high crop diversity showed strong demand for crop pollination services. Thus, both large and small farmers need continued provision of pollination services. Legal requirements can therefore be seen as an opportunity to restore natural areas that offer important services for food production and crop productivity in Brazil. Our approach is widely applicable in any country, given availability of local data. We highlight the importance of small-scale data to inform local restoration and conservation practices while helping understand broad spatial patterns of demand for NCP.

\section{ASSOCIATED CONTENT}

\section{(s) Supporting Information}

The Supporting Information is available free of charge at https://pubs.acs.org/doi/10.1021/acs.est.1c02546.

Crops included in this study; correlation between crop pollination variables; absolute area in deficit in Brazilian municipalities; demand for crop pollination in production (value of crop pollination in tonnage relative to total agricultural production); demand for crop pollination in area (value of crop pollination in area relative to total agricultural area); uncertainty in PD metrics (expressed as percentage of change in PD metrics relative to its upper and lower bounds); uncertainty in demand for crop pollination in the monetary value, production, and area; pollinator-dependent crops that contributed the most to the estimate of demand for pollination (based on crop production in ton); bars representing the number of municipalities in which a given pollinator-dependent crop contributed the most; correlation between crop pollination metrics and VDs in Brazilian municipalities; demand for crop pollination based on value, crop production, and crop area; diversity of pollinator-dependent crops; combination of demand for crop pollination in production and VD in Brazilian municipalities; municipalities classified in high restoration priority (strong/great crop PD + high deficit) and low restoration priority (low demand + high deficit); municipalities with low VD and priority scores for conservation of natural areas and maintenance of restoration efforts in relation to crop pollination: high conservation priority (strong/great demand + low deficit) and low conservation priority (low demand + low deficit); combination of demand for crop pollination in area and VD in Brazilian municipalities; municipalities classified in high restoration priority (strong/great crop $\mathrm{PD}+$ high deficit) and low restoration priority (low demand + high deficit); and municipalities with low VD and priority scores for conservation of natural areas and maintenance of restoration efforts in relation to crop pollination: high conservation priority (strong/great demand + low deficit) and low conservation priority (low demand + low deficit) (PDF)

\section{AUTHOR INFORMATION}

\section{Corresponding Author}

Pedro J. Bergamo - Rio de Janeiro Botanical Garden, Rio de Janeiro 22460-030, Brazil; 이이.org/0000-0002-49844410; Email: pjbergamo@gmail.com 


\section{Authors}

Marina Wolowski - Institute of Natural Sciences, Federal University of Alfenas, Alfenas 37130-001, Brazil

Leandro R. Tambosi - Federal University of $A B C$, Santo André 09210-580, Brazil

Edenise Garcia - Instituto de Conservação Ambiental The Nature Conservancy Brasil, São Paulo 01311-936, Brazil

Kayna Agostini - Department of Natural Science, Mathematics and Education, Federal University of São Carlos, Araras 13600-970, Brazil

Lucas A. Garibaldi - Instituto de Investigaciones en Recursos Naturales, Agroecología y Desarrollo Rural, Universidad Nacional de Río Negro, San Carlos de Bariloche 8400, Argentina; Consejo Nacional de Investigaciones Científicas y Técnicas, Agroecología y Desarollo Rural, Instituto de Investigaciones em Recursos Naturales, San Carlos de Bariloche 8400, Argentina

Tiffany M. Knight - German Centre for Integrative Biodiversity Research (iDiv), Halle-Jena-Leipzig, Leipzig 04103, Germany; Community Ecology Department, Helmholtz Centre for Environmental Research, UFZ, Halle 06120, Germany; Institute of Biology, Martin Luther University Halle-Wittenberg, Halle 06099, Germany

Eimear Nic Lughadha - Conservation Science Department, Royal Botanic Gardens, Richmond TW9 9AE, U.K.

Paulo E. A. M. Oliveira - Institute of Biology, Federal University of Uberlândia, Uberlândia 38405-302, Brazil

Marcia C. M. Marques - Botany Department, Federal University of Paraná, Curitiba 81531-980, Brazil

Pietro K. Maruyama - Centre of Ecological Synthesis and Conservation, Department of Genetics, Ecology and Evolution, Federal University of Minas Gerais (UFMG), Belo Horizonte 31270-901, Brazil

Márcia M. Maués - Laboratory of Entomology, Embrapa Eastern Amazon, Belém 66095-903, Brazil

Alberto K. Oppata - Cooperativa Agrícola Mista de ToméAçu, Tomé-Açu 68682-000, Brazil

André R. Rech - Centre of Advanced Studies on Functioning of Ecological Systems and Interactions (CAFESINMULTIFLOR), Federal University of the Jequitinhonha and Mucuri Valleys, Diamantina 39100-000, Brazil

Antônio M. Saraiva - Polythecnic School, University of São Paulo, São Paulo 055-08-010, Brazil

Felipe D. S. Silva - Rio de Janeiro Botanical Garden, Rio de Janeiro 22460-030, Brazil

Gizele Sousa - Cooperativa Agrícola Mista de Tomé-Açu, Tomé-Açu 68682-000, Brazil

Rodrigo Y. Tsukahara - Fundação ABC Pesquisa e Desenvolvimento Agropecuário, Castro 84165-700, Brazil

Isabela G. Varassin - Laboratório de Interações e Biologia Reprodutiva, Federal University of Paraná, Curitiba 81531980, Brazil

Blandina F. Viana - National Institute of Science and Technology in Interdisciplinary and Transdisciplinary Studies in Ecology and Evolution, Institute of Biology, Federal University of Bahia, Salvador 40170-210, Brazil

Leandro Freitas - Rio de Janeiro Botanical Garden, Rio de Janeiro 22460-030, Brazil

Complete contact information is available at: https://pubs.acs.org/10.1021/acs.est.1c02546

\section{Funding}

This study was funded by CNPq (SINBIOSE Call 442351/ 2019-4 and Postdoctoral fellowship to PJB no 152417/20206). P.J.B. also thanks FAPERJ (201.867/2020).

Notes

The authors declare no competing financial interest.

\section{ACKNOWLEDGMENTS}

We thank CNPq and FAPERJ for financial support.

\section{REFERENCES}

(1) Díaz, S.; Pascual, U.; Stenseke, M.; Martín-López, B.; Watson, R. T.; Molnár, Z.; Hill, R.; Chan, K. M. A.; Baste, I. A.; Brauman, K. A.; Polasky, S.; Church, A.; Lonsdale, M.; Larigauderie, A.; Leadley, P. W.; van Oudenhoven, A. P. E.; van der Plaat, F.; Schröter, M.; Lavorel, S.; Aumeeruddy-Thomas, Y.; Bukvareva, E.; Davies, K.; Demissew, S.; Erpul, G.; Failler, P.; Guerra, C. A.; Hewitt, C. L.; Keune, H.; Lindley, S.; Shirayama, Y. Assessing nature's contributions to people. Science 2018, 359, 270-272.

(2) Garibaldi, L. A.; Oddi, F. J.; Miguez, F. E.; Bartomeus, I.; Ort, M. C.; Jobbágy, E. G.; Kremen, C.; Schulte, L. A.; Hughes, A. C.; Bagnato, C.; Abramson, G.; Bridgewater, P.; Carella, D. G.; Díaz, S.; Dicks, L. V.; Ellis, E. C.; Goldenberg, M.; Huaylla, C. A.; Kuperman, M.; Locke, H.; Mehrabi; Santibañez, F.; Zhu, C.-D. Working landscapes need at least $20 \%$ native habitat. Conserv. Lett. 2020, 14, No. e12773.

(3) Kennedy, C. M.; Lonsdorf, E.; Neel, M. C.; Williams, N. M.; Ricketts, T. H.; Winfree, R.; Bommarco, R.; Brittain, C.; Burley, A. L.; Cariveau, D.; Carvalheiro, L. G.; Chacoff, N. P.; Cunningham, S. A.; Danforth, B. N.; Dudenhöffer, J.-H.; Elle, E.; Gaines, H. R.; Garibaldi, L. A.; Gratton, C.; Holzschuh, A.; Isaacs, R.; Javorek, S. K.; Jha, S.; Klein, A. M.; Krewenka, K.; Mandelik, Y.; Mayfield, M. M.; Morandin, L.; Neame, L. A.; Otieno, M.; Park, M.; Potts, S. G.; Rundlöf, M.; Saez, A.; Steffan-Dewenter, I.; Taki, H.; Viana, B. F.; Westphal, C.; Wilson, J. K.; Greenleaf, S. S.; Kremen, C. A global quantitative synthesis of local and landscape effects on wild bee pollinators in agroecosystems. Ecol. Lett. 2013, 16, 584-599.

(4) Dainese, M.; Martin, E. A.; Aizen, M. A.; Albrecht, M.; Bartomeus, I.; Bommarco, R.; Carvalheiro, L. G.; Chaplin-Kramer, R.; Gagic, V.; Garibaldi, L. A.; Ghazoul, J.; Grab, H.; Jonsson, M.; Karp, D. S.; Kennedy, C. M.; Kleijn, D.; Kremen, C.; Landis, D. A.; Letourneau, D. K.; Marini, L.; Poveda, K.; Rader, R.; Smith, H. G.; Tscharntke, T.; Andersson, G. K. S.; Badenhausser, I.; Baensch, S.; Bezerra, A. D. M.; Bianchi, F. J. J. A.; Boreux, V.; Bretagnolle, V.; Caballero-Lopez, B.; Cavigliasso, P.; Cetković, A.; Chacoff, N. P.; Classen, A.; Cusser, S.; da Silva e Silva, F. D.; de Groot, G. A.; Dudenhöffer, J. H.; Ekroos, J.; Fijen, T.; Franck, P.; Freitas, B. M.; Garratt, M. P. D.; Gratton, C.; Hipólito, J.; Holzschuh, A.; Hunt, L.; Iverson, A. L.; Jha, S.; Keasar, T.; Kim, T. N.; Kishinevsky, M.; Klatt, B. K.; Klein, A.-M.; Krewenka, K. M.; Krishnan, S.; Larsen, A. E.; Lavigne, C.; Liere, H.; Maas, B.; Mallinger, R. E.; Martinez Pachon, E.; Martínez-Salinas, A.; Meehan, T. D.; Mitchell, M. G. E.; Molina, G. A. R.; Nesper, M.; Nilsson, L.; O’Rourke, M. E.; Peters, M. K.; Plećaš, M.; Potts, S. G.; Ramos, D. d. L.; Rosenheim, J. A.; Rundlöf, M.; Rusch, A.; Sáez, A.; Scheper, J.; Schleuning, M.; Schmack, J. M.; Sciligo, A. R.; Seymour, C.; Stanley, D. A.; Stewart, R.; Stout, J. C.; Sutter, L.; Takada, M. B.; Taki, H.; Tamburini, G.; Tschumi, M.; Viana, B. F.; Westphal, C.; Willcox, B. K.; Wratten, S. D.; Yoshioka, A.; Zaragoza-Trello, C.; Zhang, W.; Zou, Y.; Steffan-Dewenter, I. A global synthesis reveals biodiversity-mediated benefits for crop production. Sci. Adv. 2019, 5, No. eaax0121.

(5) IBPES. The IPBES Assessment Report on Land Degradation and Restoration, 2018.

(6) FAO. OECD-FAO Agricultural Outlook 2019-2028, 2019.

(7) Benayas, J. M. R.; Newton, A. C.; Diaz, A.; Bullock, J. M. Enhancement of biodiversity and ecosystem services by ecological restoration: a meta-analysis. Science 2009, 325, 1121-1124. 
(8) Díaz, S.; Zafra-Calvo, N.; Purvis, A.; Verburg, P. H.; Obura, D.; Leadley, P.; Chaplin-Kramer, R.; De Meester, L.; Dulloo, E.; MartínLópez, B.; Shaw, M. R.; Visconti, P.; Broadgate, W.; Bruford, M. W.; Burgess, N. D.; Cavender-Bares, J.; DeClerck, F.; Fernández-Palacios, J. M.; Garibaldi, L. A.; Hill, S. L. L.; Isbell, F.; Khoury, C. K.; Krug, C. B.; Liu, J.; Maron, M.; McGowan, P. J. K.; Pereira, H. M.; ReyesGarcía, V.; Rocha, J.; Rondinini, C.; Shannon, L.; Shin, Y.-J.; Snelgrove, P. V. R.; Spehn, E. M.; Strassburg, B.; Subramanian, S. M.; Tewksbury, J. J.; Watson, J. E. M.; Zanne, A. E. Set ambitious goals for biodiversity and sustainability. Science 2020, 370, 411-413.

(9) Bastin, J.-F.; Finegold, Y.; Garcia, C.; Mollicone, D.; Rezende, M.; Routh, D.; Zohner, C. M.; Crowther, T. W. The global tree restoration potential. Science 2019, 365, 76-79.

(10) Fischer, J.; Riechers, M.; Loos, J.; Martin-Lopez, B.; Temperton, V. M. Making the UN Decade on Ecosystem Restoration a social-ecological endeavour. Trends Ecol. Evol. 2021, 36, 20-28.

(11) Klein, A.-M.; Vaissière, B. E.; Cane, J. H.; Steffan-Dewenter, I.; Cunningham, S. A.; Kremen, C.; Tscharntke, T. Importance of pollinators in changing landscapes for world crops. Proc. R. Soc. B 2007, 274, 303-313.

(12) Gallai, N.; Vaissière, B. Guidelines for the Economic Evaluation of Pollination Services at a National Scale; Food and Agriculture Organization, 2009 hal-02822628.

(13) IPBES. The Assessment Report of the IPBES on Pollinators, Pollination and Food Production, 2016.

(14) Garibaldi, L. A.; Steffan-Dewenter, I.; Winfree, R.; Aizen, M. A.; Bommarco, R.; Cunningham, S. A.; Kremen, C.; Carvalheiro, L. G.; Harder, L. D.; Afik, O.; Bartomeus, I.; Benjamin, F.; Boreux, V.; Cariveau, D.; Chacoff, N. P.; Dudenhöffer, J. H.; Freitas, B. M.; Ghazoul, J.; Greenleaf, S.; Hipólito, J.; Holzschuh, A.; Howlett, B.; Isaacs, R.; Javorek, S. K.; Kennedy, C. M.; Krewenka, K. M.; Krishnan, S.; Mandelik, Y.; Mayfield, M. M.; Motzke, I.; Munyuli, T.; Nault, B. A.; Otieno, M.; Petersen, J.; Pisanty, G.; Potts, S. G.; Rader, R.; Ricketts, T. H.; Rundlöf, M.; Seymour, C. L.; Schüepp, C.; Szentgyörgyi, H.; Taki, H.; Tscharntke, T.; Vergara, C. H.; Viana, B. F.; Wanger, T. C.; Westphal, C.; Williams, N.; Klein, A. M. Wild pollinators enhance fruit set of crops regardless of honey bee abundance. Science 2013, 339, 1608-1611.

(15) Rader, R.; Bartomeus, I.; Garibaldi, L. A.; Garratt, M. P. D.; Howlett, B. G.; Winfree, R.; Cunningham, S. A.; Mayfield, M. M.; Arthur, A. D.; Andersson, G. K. S.; Bommarco, R.; Brittain, C.; Carvalheiro, L. G.; Chacoff, N. P.; Entling, M. H.; Foully, B.; Freitas, B. M.; Gemmill-Herren, B.; Ghazoul, J.; Griffin, S. R.; Gross, C. L.; Herbertsson, L.; Herzog, F.; Hipólito, J.; Jaggar, S.; Jauker, F.; Klein, A.-M.; Kleijn, D.; Krishnan, S.; Lemos, C. Q.; Lindström, S. A. M.; Mandelik, Y.; Monteiro, V. M.; Nelson, W.; Nilsson, L.; Pattemore, D. E.; de O. Pereira, N.; Pisanty, G.; Potts, S. G.; Reemer, M.; Rundlöf, M.; Sheffield, C. S.; Scheper, J.; Schüepp, C.; Smith, H. G.; Stanley, D. A.; Stout, J. C.; Szentgyörgyi, H.; Taki, H.; Vergara, C. H.; Viana, B. F.; Woyciechowski, M. Non-bee insects are important contributors to global crop pollination. Proc. Natl. Acad. Sci. U.S.A. 2016, 113, 146151.

(16) Aizen, M. A.; Garibaldi, L. A.; Cunningham, S. A.; Klein, A. M. Long-term global trends in crop yield and production reveal no current pollination shortage but increasing pollinator dependency. Curr. Biol. 2008, 18, 1572-1575.

(17) Garibaldi, L. A.; Carvalheiro, L. G.; Vaissiére, B. E.; GemmillHerren, B.; Hipólito, J.; Freitas, B. M.; Ngo, H. T.; Azzu, N.; Sáez, A.; Åström, J.; An, J.; Blochtein, B.; Buchori, D.; García, F. J. C.; Oliveira da Silva, F.; Devkota, K.; Ribeiro, M. d. F.; Freitas, L.; Gaglianone, M. C.; Goss, M.; Irshad, M.; Kasina, M.; Filho, A. J. S. P.; Kiill, L. H. P.; Kwapong, P.; Parra, G. N.; Pires, C.; Pires, V.; Rawal, R. S.; Rizali, A.; Saraiva, A. M.; Veldtman, R.; Viana, B. F.; Witter, S.; Zhang, H. Mutually beneficial pollinator diversity and crop yield outcomes in small and large farms. Science 2016, 351, 388-391.

(18) Lázaro, A.; Alomar, D. Landscape heterogeneity increases the spatial stability of pollination services to almond trees through the stability of pollinator visits. Agric., Ecosyst. Environ. 2019, 279, 149155.
(19) Senapathi, D.; Biesmeijer, J. C.; Breeze, T. D.; Kleijn, D.; Potts, S. G.; Carvalheiro, L. G. Pollinator conservation-the difference between managing for pollination services and preserving pollinator diversity. Curr. Opin. Insect Sci. 2015, 12, 93-101.

(20) Bennett, J. M.; Steets, J. A.; Burns, J. H.; Burkle, L. A.; Vamosi, J. C.; Wolowski, M.; Arceo-Gómez, G.; Burd, M.; Durka, W.; Ellis, A. G.; Freitas, L.; Li, J.; Rodger, J. G.; Ştefan, V.; Xia, J.; Knight, T. M.; Ashman, T.-L. Land use and pollinator dependency drives global patterns of pollen limitation in the Anthropocene. Nat. Commun. 2020, 11, 3999.

(21) Cariveau, D. P.; Bruninga-Socolar, B.; Pardee, G. L. A review of the challenges and opportunities for restoring animal-mediated pollination of native plants. Emerging Top. Life Sci. 2020, 4, 99-109.

(22) Costanza, R.; d'Arge, R.; de Groot, R.; Farber, S.; Grasso, M.; Hannon, B.; Limburg, K.; Naeem, S.; O’Neill, R. V.; Paruelo, J.; Raskin, R. G.; Sutton, P.; van den Belt, M. The value of the world's ecosystem services and natural capital. Nature 1997, 387, 253-260.

(23) Gallai, N.; Salles, J.-M.; Settele, J.; Vaissière, B. E. Economic valuation of the vulnerability of world agriculture confronted with pollinator decline. Ecol. Econ. 2009, 68, 810-821.

(24) Lautenbach, S.; Seppelt, R.; Liebscher, J.; Dormann, C. F. Spatial and temporal trends of global pollination benefit. PLoS One 2012, 7, No. e35954.

(25) Bauer, D. M.; Sue Wing, I. The macroeconomic cost of catastrophic pollinator declines. Ecol. Econ. 2016, 126, 1-13.

(26) Porto, R. G.; de Almeida, R. F.; Cruz-Neto, O.; Tabarelli, M.; Viana, B. F.; Peres, C. A.; Lopes, A. V. Pollination ecosystem services: a comprehensive review of economic values, research funding and policy actions. Food Secur. 2020, 12, 1425-1442.

(27) Barbosa, M. d. M.; Carneiro, L. T.; Pereira, M. F. C. S.; Rodriguez, C. Z.; Chagas, T. R. F.; Moya, W.; Bergamini, L. L.; Mancini, M. C. S.; Paes, N. D.; Giraldo, L. C. P. Future scenarios of land-use-cover effects on pollination supply and demand in São Paulo State, Brazil. Biota Neotropica 2020, 20, No. e20190906.

(28) Hipólito, J.; Sousa, B. d. S. B.; Borges, R. C.; Brito, R. M. d.; Jaffé, R.; Dias, S.; Imperatriz Fonseca, V. L.; Giannini, T. C. Valuing nature's contribution to people: the pollination services provided by two protected areas in Brazil. Global Ecol. Conserv. 2019, 20, No. e00782.

(29) Barfield, A. S.; Bergstrom, J. C.; Ferreira, S.; Covich, A. P.; Delaplane, K. S. An economic valuation of biotic pollination services in Georgia. J. Econ. Entomol. 2015, 108, 388-398.

(30) Borges, R. C.; Brito, R. M.; Imperatriz-Fonseca, V. L.; Giannini, T. C. The value of crop production and pollination services in the Eastern Amazon. Neotrop. Entomol. 2020, 49, 545-556.

(31) Jordan, A.; Patch, H. M.; Grozinger, C. M.; Khanna, V. Economic dependence and vulnerability of United States agricultural sector on insect-mediated pollination service. Environ. Sci. Technol. 2021, 55, 2243-2253.

(32) Sparovek, G.; Reydon, B. P.; Guedes Pinto, L. F.; Faria, V.; de Freitas, F. L. M.; Azevedo-Ramos, C.; Gardner, T.; Hamamura, C.; Rajão, R.; Cerignoni, F.; Siqueira, G. P.; Carvalho, T.; Alencar, A.; Ribeiro, V. Who owns Brazilian lands? Land Use Pol. 2019, 87, 104062.

(33) Aizen, M. A.; Aguiar, S.; Biesmeijer, J. C.; Garibaldi, L. A.; Inouye, D. W.; Jung, C.; Martins, D. J.; Medel, R.; Morales, C. L.; Ngo, H.; Pauw, A.; Paxton, R. J.; Sáez, A.; Seymour, C. L. Global agricultural productivity is threatened by increasing pollinator dependence without a parallel increase in crop diversification. Global Change Biol. 2019, 25, 3516-3527.

(34) Viana, B. F.; Boscolo, D.; Neto, E. M.; Lopes, L. E.; Lopes, A. V.; Ferreira, P. A.; Pigozzo, C. M.; Primo, L. M. How well do we understand landscape effects on pollinators and pollination services? J. Pollinat. Ecol. 2012, 7, 31-41.

(35) IBPES. Global Assessment Report on Biodiversity and Ecosystem Services of the Intergovernmental Science-Policy Platform in Biodiversity and Ecosystem Services, 2019.

(36) Freitas, F. L. M.; Guidotti, V.; Sparovek, G.; Hamamura, C. Nota técnica: malha fundiária do Brasil, v.1812. Atlas - A Geografia 
da Agropecuária Brasileira, 2017. http://www.imaflora.org/ atlasagropecuario.

(37) Native vegetation protection act of 2012. Public Law 12.651, 2012. http://www.planalto.gov.br/ccivil_03/_ato2011-2014/2012/lei/ 112651.htm

(38) Guidotti, V.; Freitas, F. L. M.; Sparovek, G.; Pinto, L. F. G.; Hamamura, C.; Carvalho, T.; Cerignoni, F. Números detalhados do novo código florestal e suas implicações para os PRAs. Sustentabilidade em debate 2017, 5, 1-10.

(39) Melo, F. P. L.; Pinto, S. R. R.; Brancalion, P. H. S.; Castro, P. S.; Rodrigues, R. R.; Aronson, J.; Tabarelli, M. Priority setting for scalingup tropical forest restoration projects: early lessons from the Atlantic Forest Restoration Pact. Environ. Sci. Policy 2013, 33, 395-404.

(40) Rother, D. C.; Vidal, C. Y.; Fagundes, I. C.; Silva, M. M.; Gandolfi, S.; Rodrigues, R. R.; Nave, A. G.; Viani, R. A. G.; Brancalion, P. H. S. How legal-oriented restoration programs enhance landscape connectivity? Insights from the Brazilian Atlantic Forest. Trop. Conserv. Sci. 2018, 11, 1940082918785076.

(41) Giannini, T. C.; Cordeiro, G. D.; Freitas, B. M.; Saraiva, A. M.; Imperatriz-Fonseca, V. L. The dependence of crops for pollinators and the economic value of pollination in Brazil. J. Econ. Entomol. 2015, 108, 849-857.

(42) Relatório temático sobre Polinização, Polinizadores e Produção de Alimentos no Brasil; BPBES-REBIPP, 2019.

(43) Spellerberg, I. F.; Fedor, P. J. A tribute do Claude Shannon (1916-2001) and a plea for more rigorous use of species richness, species diversity and the 'Shannon-Wiener' index. Global Ecol. Biogeogr. 2003, 12, 177-179.

(44) Dias, L. C. P.; Pimenta, F. M.; Santos, A. B.; Costa, M. H.; Ladle, R. J. Patterns of land use, extensification, and intensification of Brazilian agriculture. Global Change Biol. 2016, 22, 2887-2903.

(45) Campbell, A. J.; Carvalheiro, L. G.; Maués, M. M.; Jaffé, R.; Giannini, T. C.; Freitas, M. A. B.; Coelho, B. W. T.; Menezes, C. Anthropogenic disturbance of tropical forests threatens pollination services to açai palm in the Amazon river delta. J. Appl. Ecol. 2018, 55, $1725-1736$.

(46) Projeções do Agronegócio 2018/2019 a 2028/2029; Ministério da Agricultura, Pecuária e Abastecimento: Brasilia, Brazil, 2019. https:// www.gov.br/agricultura/pt-br/assuntos/politica-agricola/todaspublicacoes-de-politica-agricola/projecoes-do-agronegocio/projecoesdo-agronegocio-2018-2019-2028-2029.

(47) Mapas Regionais; Instituto Brasileiro de Geografia e Estatística: Brasilia, Brazil, 2019. https://www.ibge.gov.br/geociencias/cartas-emapas/mapas-regionais/10861-mapas-regionais.html.

(48) Olson, D. M.; Dinerstein, E.; Wikramanayake, E. D.; Burgess, N. D.; Powell, G. V. N.; Underwood, E. C.; D’amico, J. A.; Itoua, I.; Strand, H. E.; Morrison, J. C.; Loucks, C. J.; Allnutt, T. F.; Ricketts, T. H.; Kura, Y.; Lamoreux, J. F.; Wettengel, W. W.; Hedao, P.; Kassem, K. R. Terrestrial Ecoregions of the World: A New Map of Life on Earth: A new global map of terrestrial ecoregions provides an innovative tool for conserving biodiversity. BioScience 2001, 51, 933938.

(49) Fearnside, P. M. Deforestation in Brazilian Amazonia: history, rates, and consequences. Conserv. Biol. 2005, 19, 680-688.

(50) de O. Milfont, M.; Rocha, E. E. M.; Lima, A. O. N.; Freitas, B. M. Higher soybean production using honeybee and wild pollinators, a sustainable alternative to pesticides and autopollination. Environ. Chem. Lett. 2013, 11, 335-341.

(51) Monasterolo, M.; Musicante, M. L.; Valladares, G. R.; Salvo, A. Soybean crops may benefit from forest pollinators. Agric., Ecosyst. Environ. 2015, 202, 217-222.

(52) Huais, P. Y.; Grilli, G.; Amarilla, L. D.; Torres, C.; Fernández, L.; Galetto, L. Forest fragments influence pollination and yield of soybean crops in Chaco landscapes. Basic Appl. Ecol. 2020, 48, 61-72.

(53) Barona, E.; Ramankutty, N.; Hyman, G.; Coomes, O. T. The role of pasture and soybean in deforestation of the Brazilian Amazon. Environ. Res. Lett. 2010, 5, 024002.

(54) Gollnow, F.; Hissa, L. d. B. V.; Rufin, P.; Lakes, T. Propertylevel direct and indirect deforestation for soybean production in the
Amazon region of Mato Grosso, Brazil. Land Use Pol. 2018, 78, 377385.

(55) Araújo, M. L. S. d.; Sano, E. E.; Bolfe, É. L.; Santos, J. R. N.; dos Santos, J. S.; Silva, F. B. Spatiotemporal dynamics of soybean crop in the Matopiba region, Brazil (1990-2015). Land Use Pol. 2019, 80, $57-67$.

(56) Chaplin-Kramer, R.; Sharp, R. P.; Weil, C.; Bennett, E. M.; Pascual, U.; Arkema, K. K.; Brauman, K. A.; Bryant, B. P.; Guerry, A. D.; Haddad, N. M.; Hamann, M.; Hamel, P.; Johnson, J. A.; Mandle, L.; Pereira, H. M.; Polasky, S.; Ruckelshaus, M.; Shaw, M. R.; Silver, J. M.; Vogl, A. L.; Daily, G. C. Global modeling of nature's contributions to people. Science 2019, 366, 255-258.

(57) Mier y Terán Giménez Cacho, M. Soybean agri-food systems dynamics and the diversity of farming styles on the agricultural frontier in Mato Grosso, Brazil. J. Peasant Stud. 2016, 43, 419-441.

(58) Anderson, A. B.; Overal, W. L.; Henderson, A. Pollination ecology of a forest-dominant palm (Orbignya phalerata Mart.) in Northern Brazil. Biotropica 1988, 20, 192-205.

(59) Yamamoto, M.; da Silva, C. I.; Augusto, S. C.; Barbosa, A. A. A.; Oliveira, P. E. The role of bee diversity in pollination and fruit set of yellow passion fruit (Passiflora edulis forma flavicarpa, Passifloraceae) crop in Central Brasil. Apidologie 2012, 43, 515-526.

(60) Freitas, B. M.; Pacheco Filho, A. J. S.; Andrade, P. B.; Lemos, C. Q.; Rocha, E. E. M.; Pereira, N. O.; Bezerra, A. D. M.; Nogueira, D. S.; Alencar, R. L.; Rocha, R. F.; Mendonça, K. S. Forest remnants enhance wild pollinator visit to cashew flowers and mitigate pollination deficit in NE Brazil. J. Pollinat. Ecol. 2014, 12, 22-30.

(61) Molin, P. G.; Gergel, S. E.; Soares-Filho, B. S.; Ferraz, S. F. B. Spatial determinants of Atlantic Forest loss and recovery in Brazil. Landsc. Ecol. 2017, 32, 857-870.

(62) Tittonell, P. Ecological intensification of agriculture sustainable by nature. Curr. Opin. Environ. Sustain. 2014, 8, 53-61.

(63) Garibaldi, L. A.; Pérez-Méndez, N.; Garratt, M. P. D.; GemmillHerren, B.; Miguez, F. E.; Dicks, L. V. Policies for ecological intensification of crop production. Trends Ecol. Evol. 2019, 34, 282286.

(64) Strassburg, B. B. N.; Beyer, H. L.; Crouzeilles, R.; Iribarrem, A.; Barros, F.; de Siqueira, M. F.; Sánchez-Tapia, A.; Balmford, A.; Sansevero, J. B. B.; Brancalion, P. H. S.; Broadbent, E. N.; Chazdon, R. L.; Filho, A. O.; Gardner, T. A.; Gordon, A.; Latawiec, A.; Loyola, R.; Metzger, J. P.; Mills, M.; Possingham, H. P.; Rodrigues, R. R.; Scaramuzza, C. A. d. M.; Scarano, F. R.; Tambosi, L.; Uriarte, M. Strategic approaches to restoring ecosystems can triple conservation gains and halve costs. Nat. Ecol. Evol. 2019, 3, 62-70.

(65) Chazdon, R. L.; Guariguata, M. R. Natural regeneration as a tool for large-scale forest restoration in the tropics: prospects and challenges. Biotropica 2016, 48, 716-730.

(66) Rocha, C.; Burlandy, L.; Maluf, R. Small farms and sustainable rural development for food security: The Brazilian experience. Dev. South Afr. 2012, 29, 519-529.

(67) A agricultura no nordeste brasileiro: oportunidades e limitações ao desenvolvimento; Instituto de Pesquisa Econômica Aplicada: Brasilia: Brazil, 2012. https://www.econstor.eu/handle/10419/91269.

(68) Altieri, M. A.; Toledo, V. M. The agroecological revolution in Latin America: rescuing nature, ensuring food sovereignty and empowering peasants. J. Peasant Stud. 2011, 38, 587-612.

(69) Burkhard, B.; Kroll, F.; Nedkov, S.; Müller, F. Mapping ecosystem service supply, demand and budgets. Ecol. Indicat. 2012, 21, 17-29.

(70) Koh, I.; Lonsdorf, E. V.; Williams, N. M.; Brittain, C.; Isaacs, R.; Gibbs, J.; Ricketts, T. H. Modeling the status, trends, and impacts of wild bee abundance in the United States. Proc. Natl. Acad. Sci. U.S.A. 2016, 113, 140-145. 